\title{
Valor estético de la intuición metafísica en el Diario de un poeta recién casado, de J.R. Jiménez
}

\section{Aesthetic Value of Metaphysical Intuition in Diary of a Newlywed Poet, by J.R. Jiménez}

\section{María Luisa Amigo}

Facultad de Ciencias Sociales y Humanas. Universidad de Deusto. Bilbao, España.

mlamigo@deusto.es

\section{Resumen}

En el centenario de la creación del Diario de un poeta recién casado de J.R. Jiménez, este trabajo profundiza en su descubrimiento metafísico. A partir de los conceptos de la estética del poeta, se va descubriendo en los poemas la búsqueda de sentido que se trasluce tras la clave del enriquecimiento sensitivo, la comprensión de la realidad y el estímulo de la conciencia del receptor. De este modo, se realiza el estudio en el triple sentido de los cultivos, término mediante el cual sostuvo una teoría de desarrollo humano, cultivo de la sensibilidad, la inteligencia y la conciencia.

Palabras clave: Juan Ramón Jiménez, intuición metafísica, cultivo, sentido.

\section{Abstract}

At the centenary of the creation of Diary of a Newlywed Poet, this paper elaborates on its metaphysical discovery. Building on the relevant concepts of the poet's aesthetics, it discovers the search for meaning in the poems in the light of sensitive enrichment, the understanding of reality and the stimulation of the receiver's conscience. The study was performed in the triple sense of cultivation, term under which the poet held a theory of human development, as cultivation of sensitivity, intelligence and conscience.

Keywords: Juan Ramón Jiménez, metaphysical intuition, cultivation, meaning. 


\section{Introducción}

En 1916, Juan Ramón Jiménez escribió Diario de un poeta recién casado. Se ha cumplido un siglo de la creación de este poemario clave en el conjunto de su obra y trascendente para la historia de la literatura. El propio poeta lo destacó como su mejor libro, y así también lo expresó a Ricardo Gullón en 1953 (92). La crítica posterior le ha dado la razón, incluso se ha sostenido que se puede hablar de la poesía española antes y después del Diario, valoración similar a la que se le otorga a las Soledades de Góngora en el Barroco (Rozas 149). Este poemario es reconocido como "uno de los libros fundamentales en la historia de la poesía española de todos los tiempos" (Blasco 5). Juan Ramón Jiménez se refirió a su libro como uno "metafísico en el que se tratan los problemas de la creación poética, los problemas del encuentro con las grandes fuerzas naturales el mar, el cielo, el sol, el agua" (Gullón 91). Esta reflexión sitúa el texto en un horizonte de búsqueda de sentido, tal y como el poeta comprendió la experiencia poética creadora y recreadora.

En este trabajo me propongo apuntar algunas dimensiones de su valor para el recreador o participante. El propio autor sostuvo una teoría de desarrollo humano que expondré en adelante. ¿Contribuye la dimensión metafísica anunciada por Jiménez al enriquecimiento del lector? Desearía responder a esta pregunta y, por ello, el objetivo general apunta a manifestar el descubrimiento metafísico que realiza este poemario, especialmente en su contribución al despliegue de la sensibilidad, la inteligencia y la conciencia del participante o recreador de la obra. Me aproximaré a la comprensión de estos conceptos en la estética del poeta y analizaré de los poemas en clave del enriquecimiento sensitivo, la comprensión de la realidad y el estímulo de la conciencia del receptor.

\section{Acercamiento al texto y a los conceptos estéticos}

El Diario tiene una metafísica que participa de estética Diario de un poeta recién casado, Juan Ramón Jiménez

Juan Ramón Jiménez sostiene en conversación con Ricardo Gullón que “con el Diario empieza el simbolismo moderno en la poesía española. Tiene una metafísica que participa de estética, como en Goethe" y valoró que "la mitad de la poesía moderna, en España, viene del Diario" (Gullón 93, 90). No voy a entrar en las apreciaciones críticas que no son objeto de este estudio (Blasco 6; Azam) y solo las recuerdo para resaltar su trascendencia; pero sí centraré mi mirada en la metafísica que participa de estética y en su contribución al despliegue de la sensibilidad, la inteligencia y la conciencia del participante o recreador de la obra. 
El libro se publicó, por primera vez, en 1917, con el título de Diario de un poeta recién casado. Como es sabido, esta obra la escribe Jiménez con motivo de un viaje a Nueva York, donde contrae matrimonio con Zenobia Camprubí, en marzo de 1916. En 1948 se publica otra edición, en la que se modifica el título a Diario de poeta y mar, destacando la relevancia que tuvo el mar en su gestación. Al oleaje del mar atribuye el verso libre, una novedad en el conjunto de su obra (Corriente 174) y relevante para este trabajo "el descubrimiento del mar, del amor y del cielo" (Gullón 84). ${ }^{1}$ Estas palabras anuncian la riqueza metafísica del libro. La edición de Aguilar, de 1957, vuelve a poner el título original por indicación del autor, aunque juntando ahora las dos últimas palabras en una sola para quedar como: Diario de un poeta recién casado y, finalmente, como Diario de un poeta recién casado, en la edición de Espasa de 2005. Juan Ramón Jiménez (Corriente 157) y la crítica en general han visto que con el Diario comienza una nueva etapa en su poesía, pero más que una ruptura con la obra anterior, significa la culminación de un cambio, ya ha iniciado en Sonetos espirituales y Estío. Dicho cambio hay que encuadrarlo en su concepción de una "obra en marcha" o "poesía en sucesión", cuyo cambio no se comprende como una ruptura absoluta (Albornoz 53).

Es necesario destacar que el poemario se organiza como un diario, ya que los poemas están fechados y localizados a partir de enero de 1916, durante en su viaje a América, salvo e la última sección que se titula: "Recuerdos de América del Este escritos en España”. El libro lo entregó a la imprenta en septiembre del mismo año.

La crítica destaca cómo el poeta apunta lo visto y vivido, fijando de modo desnudo, preciso y escueto sus impresiones (Azam; Blasco) y vivencias que son clarificadas y analizadas. Por ello, en el Diario contrastan los poemas de gran hondura lírica y un alto contenido simbólico, con otros que, a primera vista, parecen apuntes, anécdotas, collages, caricaturas del mundo americano. Ahora bien, este arraigo inicial en las impresiones, emociones e incidentes no contradice la autorreferencialidad del poema en tanto obra creada, que se basta a sí misma. Este carácter del poemario manifiesta su valor experiencial y no significa que sea un diario intimista y sentimental, más bien expone un nuevo estilo que renueva el género (Blasco; Pérez Priego). El autor reconoció que "el único libro que escribí de un tirón fue el Diario. Es el único concebido como tal libro y escrito inmediatamente. Y tan pronto como lo escribí, lo publiqué; después seguí reeditándolo en la misma forma, sin corregirlo" (Gullón 83-4). Eso no significa que no descartara algunos poemas o no los corrigiera, pero sí singulariza su tono experiencial que conserva en el mismo título. Él mismo coloca al frente del poemario un texto en prosa donde indica que el libro consiste en una aventura espiritual, subrayando el valor de la vivencia y del presente, como veremos en los próximos apartados.

1 La reflexión estética del poeta se encuentra en diferentes textos publicados tras su muerte. Para no confundir al lector, cito el texto abreviado en una palabra de su título. 


\section{La experiencia creadora y recreadora en la estética juanramoniana}

A lo largo de su vida, Juan Ramón Jiménez escribió diversos textos en los que fue condensando sus ideas estéticas: El trabajo gustoso (1961), El modernismo (Notas de un curso, 1953 (1962), La corriente infinita (1966), Estética y ética estética (1967), Crítica paralela (1975), Alerta (1983), Y para recordar por qué he venido (1990, Ideolojía (1990), ${ }^{2}$ Política poética (1992), publicados tras su muerte. En su fructífera concepción de la experiencia creadora resaltan rasgos metafísicos en el vínculo con la contemplación y la comprensión. La creación poética es un descubrimiento y está relacionada con el intento de buscar sentido a la realidad. Ello lo expresa en varios de sus textos: "No hemos venido al mundo para vivir, sino para descifrarlo mientras vivimos" (Aforismos 32). El autor destaca la donación de sentido como un estado de gracia. Surge de un hallazgo, de un encuentro, que provoca en el poeta, el éstasis dinámico (Corriente 148) y el indecible milagro palpitante (Trabajo 40). Su concepción de la creación poética no tiene que ver con una expresión sentimental o un desahogo intimista, más bien refiere a una búsqueda de sentido, con una apertura al ser y al conocimiento (Ideolojía 643). De allí que escriba, "la poesía se caracteriza por su intuitiva metafísica" (Trabajo 40), es decir, una apertura al sentido y a la trascendencia. La poesía pone en movimiento nuestro ser y es éxtasis dinámico: "La poesía es una íntima, profunda (honda y alta) fusión, en nosotros, y gracias a nuestra contemplación y creación, de lo real que creemos conocer y lo trascendental que creemos desconocer" (Trabajo 40). Ahora bien, este éxtasis precisamente dinámico, no es para él ensimismamiento y presencia ausente, sino acción creadora, porque la poesía es contemplación con creación. El autor reconoce la intensidad y la energía concentrada en la creación como una experiencia óptima (Csikszentmihalyi), una vivencia de gran intensidad, que parece borrar las fronteras de su psiquismo con la actividad que realiza. El estado de conciencia está en armonía y el esfuerzo del poeta se concentra en la palabra. La experiencia creadora es intensa y el poeta invierte en ella un gran esfuerzo de concentración, por eso la reconoce como satisfactoria y no dolorosa. En otro texto más teórico, Juan Ramón se refiere a los estados de contemplación de lo inefable como "comunicación y hallazgo, entrada en la naturaleza y el espíritu, en la realidad visible y la invisible" (Crítica 211). Las disposiciones del hombre para estos estados son "sentimiento, pensamiento y acento". El resultado, mudo o escrito, "emoción universal” (Trabajo 36). El poeta expresa la gozosa responsabilidad por encontrar la palabra, de ese modo la creación poética constituye un auténtico hallazgo que debe merecer: "Cuando escribo desaparezco por completo; no me siento siquiera, soy todo idea o todo sentimiento, todo palabra,

2 Como es habitual se respeta la peculiar ortografía juanramoniana respecto a los sonidos $g e$, gi, que él escribió con $j$ y el empleo de $s$ en vez de $x$. Así lo han hecho sus editores respetando la grafía $j$ en títulos como, por ejemplo, Ideolojía. 
nombre [...] Cuando yo creo, lo hago lleno de gozo, cantando, aunque la escritura sea triste" (Corriente 244). La experiencia de creación lleva consigo el gozo. Observemos que el placer no es un objetivo buscado o añadido a la actividad sino inherente a la acción misma. El autor orienta su creación a la búsqueda de sentido, que expresa de diferentes formas. El receptor acoge la obra creada y realiza una experiencia sensible e inteligible, de comprensión de sentido. Se produce también un placer intelectual, el placer estético. Veamos cómo lo desarrolla él mismo.

La experiencia de la poesía no es privativa de quien la crea. En diversos textos se refiere a la apertura de la poesía a todo hombre que sea capaz de experimentarla. Debemos a Jiménez un término preciso que condensa en una palabra la recepción vivencial del arte y la realización poética. La expresión preferida por él es el hombre "gustoso". No se trata de cualquier lector, sino de aquel que participa "simpáticamente", vivencialmente en la emoción. La palabra elegida conlleva una dimensión placentera: "Lo importante en la poesía, para mí, es la calidad de eternidad que puede un poema dejar en el que lo lee sin idea de tiempo, calidad concentrada que le será al gustoso como un inacabable diamante ideal, breve, hecho con un aura inmensa. El poema es semilla más que fruto alma secreta de una vida cualquiera" (Corriente 178). La poesía es semilla más que fruto cerrado; es germen fecundo que alcanza su consumación cuando una persona la integra valorativa y placenteramente en su propio yo. Se pone en juego la dimensión poética del hombre, que se manifiesta no solo en la creación de la obra, sino que también en la recepción. Un buen poema lleva consigo calidad de eternidad capaz de producir en el lector -no en cualquier lector, sino en el "gustoso"-, el gozo inmenso de lo pleno. La poesía, en su genuina donación, es semilla, germen fecundo que a los ojos del gustoso se irá convirtiendo en diamante: "La gran poesía 'difícil' comunica por soplo, imán, majia, fatalismo, como fue creada, y no por análisis metódico, su secreto profundo”(Ideolojia 392).

Por tanto, la poesía es vivencia, fenómeno poético que el hombre experimenta como canto y emoción, es decir, no como razón, sino como pasión (Modernismo 97, 191). Para ello pide Jiménez que "todo trabajo artístico debe ser deleitable. Donde acabe el deleite, acaba la creación, la corrección, la lectura, todo" (Ideolojía 261, 739). La creación concierne a "lo emocional que es su único reino" (Ideolojía 368).

\section{Los cultivos}

La experiencia poética puede proporcionar al lector estados de satisfacción y armonía valiosos en sí mismos. Pero Juan Ramón Jiménez apuntó las posibilidades formativas intrínsecas a esta vivencia o, en otros términos, los beneficios que puede aportar (Amigo; Sanz). Deseaba que su poesía contribuyera a fomentar en el hombre "los tres cultivos eternos: el de la intelijencia, el de la sensibilidad y el de la conciencia" (Aforismos 122), en suma, todas las facetas humanas necesarias para que se desarrolle 
en plenitud. Sostenía que la poesía debe impregnar la vida y ayudar al crecimiento consciente y armónico que lo realizan como ser humano. El poeta puntualiza cómo debemos entender esta ayuda al desarrollo del "hombre completo", que no quiere decir hombre pequeño ni superhombre (Ideolojía 595). El despliegue de nuestras capacidades nos remite al interior del ser humano y a su quehacer consigo mismo, a su tarea prioritaria de configurar su dimensión personal. El dominio sobre sí mismo y la autarquía de la personalidad moral requieren la comprensión de una escala de valores que perfile la dimensión a seguir. Ni la riqueza, ni la fama, ni los honores son la razón primera del hombre, sino el cultivo de la inteligencia, la sensibilidad y la conciencia. Este triple cultivo es la clave del desarrollo humano y, por tanto, de la acción en el seno de la sociedad. El hombre, preocupado por la trayectoria de su vida y la trascendencia de su acción en la comunidad, asume la misión de su propia formación. El poeta concreta la función formativa y educadora de la poesía en los tres cultivos eternos, tres esferas íntimamente vinculadas en la unidad de la persona. Son tres dimensiones del ser cultivado, que, en el ideal de realización del poeta, marcan tres direcciones cruzadas, entrelazadas y no paralelas. Podríamos entender los tres términos como las acciones de sentir, comprender y compartir, siempre desde la visión unitaria que deberían tener en el hombre cultivado y equilibrado.

\section{Contribución del Diario a la experiencia recreadora}

Procedo, a continuación, a esbozar una lectura del Diario de un poeta recién casado desde los cultivos, es decir, desde aportación a la sensibilidad, la inteligencia y la conciencia del que lo recrea. Esta lectura del texto se focalizará en la dimensión metafísica del mismo y su contribución al lector en el despliegue de las tres capacidades apuntadas.

\section{La sensibilidad inteligente o una nueva forma de ver}

El término sensibilidad en el horizonte de la estética se concreta, fundamentalmente, en la capacidad que tenemos los seres humanos de sentirnos afectados por las obras de arte y la posibilidad de experimentar sentimientos estéticos. Hace referencia también a nuestra facultad de captar la dimensión sensible de la obra que se percibe a través de los sentidos. Ahora bien, en la experiencia estética esta captación no es meramente sensible sino, a la vez, inteligible, como bien lo expresó el autor, subrayando la estrecha vinculación de lo sensible y lo inteligible, en los términos de "sensibilidad inteligente o inteligencia sensitiva” (Corriente 192, 255). Juan Ramón Jiménez deseaba que su obra pudiera contribuir a mejorar la calidad humana y lo expresó en diversos textos: "Mi libertad consiste en tomar de la vida y de la crítica de la vida lo que me parece mejor para mí, para todos, con la idea fija de aumentar cada día la calidad general humana, sobre todo en la sensibilidad" (Alerta 51). En el marco de esta concepción, 
paso ahora a apuntar la orientación metafísica de Diario de un poeta recién casado y su aporte al cultivo de la sensibilidad inteligente, a partir del análisis a la renovación de la mirada en tanto intuición metafísica.

He apuntado antes la nota experiencial que caracteriza al Diario, recogida en el mismo título del poemario y enmarcada en las dos prosas del inicio del texto. En la primera, a modo de prólogo, el poeta destaca el carácter vivencial de su escrito: "En este álbum de poeta copié, en leves notas, unas veces con color solo, otras solo con pensamiento, otras con luz sola, siempre frenético de emoción, la isla que la entraña prima y una del mundo del instante subía a mi alma, alma de viajero, atada al centro de lo único por un hilo elástico de gracia" (Diario 55). El otro texto, "Saludo del alba", lo recoge del sánscrito y es un canto al cuidado del presente: “Cuida bien este día! Este día es la vida, la esencia misma de la vida. En su leve transcurso se encierran todas las realidades y todas la variedades de su existencia" (Diario 56). Ambos textos ayudan a situar la mirada fenoménica del creador. Tal mirada creadora se complementa con el esfuerzo de comprensión que late en todo el poemario y se concreta en el escrito, es decir, una realidad creada nueva, que muestra una nueva forma de ver (Blasco 27, Jauss). Esta metáfora no se circunscribe a la visión sensible, más bien se encuadra en el horizonte de comprensión de la realidad y en la intuición metafísica como tarea de la poesía.

En el Diario el poeta realza la realidad sensible en tanto fenómeno en que el yo poético y la realidad son una sola donde prima el valor de la sensación. De allí su valor metafísico y cognoscitivo. El poema XLII, fechado el 6 y 7 de febrero, lleva por título "Sensaciones desagradables”: “¿Quién me ha echado tiza en los ojos? Mar y cielo se me funden en un solo blanco crudo. No sé si al norte, si al sur, si al este, si al oeste, un agujero naranja. ¡Qué dolor aquí en mis ojos! ¡Ay! ¿Herida, grito, el sol... o qué?" (Diario 86). El oleaje y la espuma marina se han fundido en la mirada del yo, rompiendo las categorías de la temporalidad y centrando el punto en el sol, un agujero naranja. En el poema LIV, "Llegada ideal”, dedicado a Joaquín Sorolla, alude a Turner: "De pronto, se abre la tarde, abanico de oro, como una gran ilusión real. ¡Qué bienestar nos entra, qué dulzura! Parece que lo estuviera viendo Turner con nosotros" (Diario 93). Se privilegian las sensaciones al tiempo que el texto nos sitúa en el espacio del barco y se expresan preguntas como “¿Dónde estamos? ¿De qué tiempo somos? ¿De qué novela hemos salido? ¿Somos una estampa?” (Diario 94). La ruptura espacio temporal es una constante del poemario. El presente es llevado al poema en un proceso temporal que le dota de una temporalidad propia, rompiendo así las barreras de espacio y tiempo, y situando en la realidad creada lugares distantes como Sevilla y Triana, en el viaje de Boston a Nueva York o artistas como Monet, Emily Dickinson, Longefellow (poema LXIX). Este nuevo espacio-tiempo del poema se comprende desde la plenitud del instante, tema recurrente en su poesía. Observemos el siguiente poema (XCVI), fechado en New Jersey, 12 de abril: "Abril, dulce, / me lleva / a todo, en esta sola hoja/ de yerba.../ - iQué bien se está, contigo, / en todas partes, 
¡nueva,/ aislada, solitaria/ primavera!” (Diario 123). La misma idea se encuentra en poemas como CIII, “Abril” o CVII, “¿Primavera?”, entre otros.

La mirada fenoménica resalta la visión de la naturaleza en la ciudad de Nueva York. En este sentido son numerosos los poemas donde el creador sabe ver la naturaleza en medio de la ciudad, destacando los árboles, las nubes, los pájaros o los cementerios, espacios de remanso en la urbe. El poema CIX, "El árbol tranquilo", es uno de ellos, situado en la "Quinta Avenida", muy cerca de la casa de Mark Twain. El yo poético se identifica con el árbol en una experiencia de armonía hacia la realidad invisible: "Y mis ojos, enredándose por sus ramas, son flor suya, y con él ven la noche alta, solo yo como él, que ha encendido, igual que mi corazón su sangre, su aceite puro, a la eterna realidad invisible de la única y más alta -y siempre existente- primavera" (Diario 129-30). Volveré más adelante sobre el concepto de realidad invisible.

El goce estético y la comprensión del poema son inseparables de las palabras que configuran los versos, de su ritmo o de las imágenes que evoca en nosotros; la profundidad está fundida con el color, la música, la sensualidad (Ideolojía 456). El Diario es un texto novedoso en su forma: se incorporan anuncios, letreros, rastros de sueños, auténticos collages que han sido valorados por la crítica. El poema CXI, "La luna", expresa una visión de Broadway, con sus anuncios luminosos, "mareantes de colorines", y surge la duda de si la luna es realidad o bien un anuncio. Los dos poemas que se titulan "Mar de pintor" (CLVIII y CLXV) constituyen apuntes de los colores del mar en las diferentes horas del día, desde la madrugada a la tarde.

El poeta destaca a lo largo del poemario el valor de la realidad sensible, exaltada en su manifestación fenoménica y creada en palabra. En esta clave se pueden leer poemas como "Iris de la tarde" (CLXXIX), "Amanecer" (CLXXXI) y "Mediodía" (CLXXXIV). Tal reconocimiento es correspondido con la conciencia de una experiencia creadora que sabe ver y dotar de palabra esa riqueza. Como veremos enseguida, en el siguiente apartado, el poeta nombra, crea y confiere así otra dimensión a la realidad que se alza hasta su nombre. No extraña en este proceso que el poeta se refiera al "agua humanizada": "La sugestión del agua humanizada es evidente. De tal modo llama su oculta belleza, que con solo decirle a nuestra alma: <Vente>, se la lleva" (Diario 184). El agua humanizada reclama al yo poético. El texto recoge un recuerdo a poetas y músicos como Verlaine, Debussy o Dulac.

En el poema CC, "Cádiz", la ciudad se refleja en el botón de su puño: "En el botón de oro de mi puño, Cádiz, un poquito más pequeña que es, se refleja toda, tacita de oro, ahora. [...] -Ahora yo hago la noche con mi manga. Cádiz no existe-" (Diario 196-7). En este texto se singulariza la primacía del fenómeno y la conciencia de la mirada creadora del poeta en la intuición metafísica. En suma, con ello, se pone de manifiesto la riqueza de la poesía del Diario que patenta la realidad creada en tanto encuentro fenoménico con la naturaleza, exaltada en su dimensión sensible y su valor cognoscitivo para la experiencia recreadora. Ofrece, de ese modo, al lector un ámbito de renovación de su mirada enriqueciendo su sensibilidad. Favorece a quien participa 
de su lectura de una mayor conciencia de sus sentidos en la apertura a la realidad. El Diario, por tanto, singulariza fenómenos de la naturaleza de manera inédita e invita a descubrir y disfrutar del vínculo que el ser humano puede tener con ella.

\section{La inteligencia sensitiva y el deseo de comprender}

Tal como ya se sostuvo más arriba, la mirada fenoménica se complementa con el esfuerzo de comprensión que late en todo el poemario. La realidad creada nos enseña una nueva forma de ver y se encuadra en el horizonte de comprensión de la realidad. Estas ideas convergen en el pensamiento del poeta en su concepción de la inteligencia sensitiva o sensibilidad inteligente: "Yo creo en el espíritu humano [...] y considero el espíritu como intelijencia sensitiva, y si añado eléctrica mejor" (Política 489).

La poesía instaura con sus medios propios una realidad distinta a la sensible y material: crea un orden nuevo, pone de manifiesto una nueva dimensión de realidad, la realidad creada. Esto no significa que el artista se aleje a una esfera idealizada que nada tiene que ver con el mundo en que vivimos. Al contrario, al artista le interesa este mundo, el único que tenemos, pero le interesa ahondarlo, descubrirlo, configurarlo en nuevas visiones. Escribe Cassirer que el arte "constituye una de las vías que nos conducen a una visión objetiva de las cosas y de la vida humana. No es una imitación sino un descubrimiento de la realidad" (213). En esta línea, el autor señala: "Cuando yo quiero volar, no es para ir al cielo de éste o el otro creyente, con un dios más o menos parecido de especie a nosotros, sino para conocer lo más y lo mejor posible este universo que mis ojos ven desde dentro de él con la luz del sol y las estrellas, y a cuyos infinitos mi conciencia, inmensa como ellos, puede llegar" (Ideolojía 711). Dicho deseo de conocimiento se muestra en muchos poemas del Diario. Observemos, por ejemplo, el poema 190 o el CLXVI, “¡El mar acierta!”:

No sé si es más o menos. Pero sé que el mar, hoy, es el mar. [...] Hoy el mar ha acertado, y nos ofrece una visión mayor de él que la teníamos de antemano, mayor que él hasta hoy. Hoy le conozco y le sobreconozco. En un momento voy desde él a todo él, a siempre y en todas partes él.

Mar, hoy te llamas mar por vez primera. Te has inventado tú mismo y te has ganado tú solo tu nombre, mar (Diario 170).

Son muchos los poemas de Diario dedicados al conocimiento del mar. Por ejemplo, XLI, "Mar": "Parece, mar, que luchas/ - ¡oh desorden sin fin, hierro incesante!-/ por encontrarte o porque yo te encuentre" (Diario 86). La admiración por la plenitud de su naturaleza, una y siempre diversa, se vuelve patente en textos como este o el poema XL, también titulado "Maro" en el poema CLXXIII. Pero este descubrimiento del mar no resulta independiente de la acción creadora del poeta. Es la palabra creadora la que fecunda lo real, lo amplía, valora y condensa en el poema. Así se dota a la realidad de nuevos ámbitos de inteligibilidad. El arte tiene una función ontológica en cuanto a 
que su misión no consiste en imitar la realidad sensible, sino en trascenderla, profundizarla, elevarla a un orden nuevo, en una palabra, crear un mundo. Esta ampliación de la realidad es vivenciada por el poeta como una creación original, divina, cuya misión es nombrar: "El poeta es un condenado a nombrar y su gloria única, que es gloria interior, está en perder su nombre en el de las cosas, el mundo, hasta quedarse anónimo por su incorporación, incorporarse por lo creado al mundo. [...] Un poeta ha de aumentar el mundo en alguna forma y manera por su pensamiento, su sentimiento o su espresión" (Crítica 145). El esfuerzo de comprensión culmina en la palabra que nombra y, por ello, reconoce: "Te has inventado tú mismo y te has ganado tú solo tu nombre, mar" (Diario 170). Además, en el poema Cvi, lo poetiza destacando el camino de depuración de su poesía conseguida con "los mínimos elementos”: “¿Sencillo?/ Las palabras/ verdaderas;/ lo justo para que ella, sonriendo/ entre sus rosas puras de hoy,/ lo comprenda./ Con un azul, un blanco, un verde/ -justos-,/ se hace -¿no ves?-la primavera" (Diario 127-8). El mar se humaniza a la medida que es contemplado y hecho palabra. Así en los poemas CLXII y CLXVIII. En la misma línea el poema LX, "Sky": "Como tu nombre es otro/ cielo, y su sentimiento/ no es mío aún, aún no eres cielo./ Sin cielo, ¡oh cielo! estoy/ pues estoy aprendiendo/ tu nombre, todavía.../ ¡Sin cielo, amor!/ - ¿Sin cielo?" (Diario 101). El nombre no revela nada al poeta hasta que se apropie de la realidad y la exprese en poema (Blasco 287).

El poemario trasluce el deseo de conocer, comprender y mostrar la experiencia de la realidad nueva creada. Tal concepción de su estética será un eje vertebral de toda la obra de Jiménez y, especialmente, a partir de la llamada segunda época. Así lo reconoce en diversos textos, como en este, "El único saber":

Hemos venido solamente para comprender por qué y para qué hemos venido. Y el único saber que puede compensarnos en nuestro papel de ignorantes en la representación humana sucesiva (de nuestro volver a lo otro oscuro sin el seguro secreto entre cuyo sol anduvimos tanto) es el amor de nuestra materia animada por la semilla de la sucesiva verdad completa (Para recordar 171).

Junto con esta voluntad de conocimiento, hay otro pilar que sustenta esta conciencia de apropiación del mundo desde el yo: el poeta es quien dona significado a las cosas en la medida en que tiene ojos para la realidad y la recrea en el arte. Por tanto, el poeta está abierto a la realidad, no es una cosa entre cosas, sino una persona capaz de comprender. Este es el significado del término inteligencia, su primera acepción del DRAE, y es también el núcleo de la experiencia estética que presenta el autor. En el poema CLXXxix, "Ciego", leemos: "De pronto, esta conciencia triste/ de que el mar no nos ve; de que no era/ esta correspondencia mantenida/ días y noches por mi alma/ y la que yo le daba al mar sin alma,/ sino un amor platónico./ ¡Sí, inmensamente/ ciego” (Diario 186-7). Gracias a la mirada creadora, el poeta es reconocido en su plenitud; sin esta, él es ciego, ya que el mar no nos ve. Podemos recordar aquí a Francastel, quien destaca que el arte nos ayuda a detener nuestra mirada, enseñándonos a ver de forma 
privilegiada objetos, personas o acontecimientos: “Debe estudiarse porque él (el arte) hace posible un desmenuzamiento de lo real según modalidades de percepción particular [...]. Pone a disposición de los individuos y de las sociedades un instrumento propio para explorar el universo sensible y el pensamiento" (115).

La inteligencia sensitiva condensa su acción creadora en una nueva palabra que es comprensión de la realidad. El poeta expresa esta idea en diferentes textos: "Será, pues, la poesía una íntima, profunda (honda y alta) fusión en nosotros, y gracias a nuestra contemplación y creación, de lo real que creemos conocer y lo trascendental que creemos desconocer" (Trabajo 37). De modo que la contemplación con creación se realiza en palabra o, lo que es lo mismo, en "volver a hacer el mundo como mi alma" (Obra poética I 2, 377). La realidad creada nos invita, entonces, a comprender esa nueva visión del mundo encarnada en forma; es palabra que condensa un descubrimiento, una apropiación del mundo, “contemplación con creación” porque: "Hay alrededor de nosotros una vida espiritual que acecha los menores instantes de esta pobre vida llena de obligaciones absurdas, para llenar el vacío -que es la plenitud, la única vida-, de imágenes que son la absoluta felicidad. ¿No será esto la promesa de una vida del porvenir, pura, clara, ideal, libre de toda traba, y hacia la cual vamos caminando?" (Ideolojia 39). Para ella, el poeta forja el concepto de realidad invisible. La realidad creada es realidad invisible, fuerza ideal, vida espiritual. Aparece expresamente en el Diario de un poeta recién casado, La rosa y la negra, y da título a una obra, La realidad invisible (1917-1924). El hablante visualiza una escena en la que una mujer negra lleva una rosa blanca viajando en el metro de Nueva York. La realidad invisible se manifiesta transformando el ambiente:

Una realidad invisible anda por todo el subterráneo, cuyo estrepitoso negror rechinante, sucio y cálido, apenas se siente. Todos han dejado sus periódicos, sus gomas y sus gritos; están absortos, como en una pesadilla de cansancio y de tristeza, en esta rosa blanca que la negra exalta y que es como la conciencia del subterráneo. Y la rosa emana, en el silencio atento, una delicada esencia y eleva como una bella presencia inmaterial que se va adueñando de todo, hasta que el hierro, el carbón, los periódicos, todo, huele un punto a rosa blanca, a primavera, a eternidad (Diario 119-20).

En la misma dirección puede leerse el poema CLIV, "Puerto", visión de Manhattan ante la figura de la estatua de la libertad, en la que el atardecer transforma el paisaje del puerto, hasta el punto que, en ocasiones, el yo poético parece fundirse con la realidad, como en el poema CLXXXII, "Oro mío": "Vamos entrando en oro. Un oro puro/ nos pasa, nos inunda, nos enciende,/ nos eterniza./ ¡Qué contenta va el alma/ porque torna a quemarse,/ a hacerse esencia única,/ a transmutarse en cielo alto!" (Diario 182). En "La casa colonial”, poema LXXviII, la realidad invisible (Blasco 292) contrasta con la casa real "que se ha quedado sola en Riverside Drive, pequeña y sola [...]. Pero en su soledad sepulcral emana tal fuerza de vida que, en una superposición 
de líneas y colores, el campo suyo antiguo despinta, aleja y borra, en fin, las terribles moles de hierro y piedra que la ahogan" (Diario 113).

Concluimos este apartado destacando el esfuerzo del texto por crear la palabra para su contemplación, goce y comprensión: "La poesía es lo único que siempre sigue respondiendo preguntas, que son, contestadas por ella, la suprema adivinación de la vida íntima de los elementos, el agua, el fuego, el aire, la tierra" (Para recordar 196197). De ese modo, el poeta da forma a los interrogantes realizándolos en palabra, ampliando en el poema la realidad de nuestro mundo. Con ello favorece el desarrollo de la comprensión del lector y le ayuda a cuestionar su visión de la realidad.

\section{Conciencia coparticipada}

Juan Ramón Jiménez pensaba que el arte es capaz de erigir paradigmas y valores, impulsando formas superiores de vida, es decir, que posibilitaba la transformación del propio yo del poeta y un cauce para la mejora de los receptores. La poesía sería entonces un camino que conduce a un estado superior, un "alimento espiritual" que abre la mirada a otra realidad. El concepto de conciencia se relaciona con la acción transformadora, creadora del propio sujeto sobre sí mismo, en la línea del pensamiento clásico desde Sócrates y Platón. A partir de Eternidades y, especialmente, en poemarios posteriores, alude al dualismo en términos de forma y de conciencia. Su forma, a modo de materia, está destinada a desaparecer; pero no así su conciencia, que sobrevivirá integrándose en la totalidad, en la unidad del universo:

El hombre espiritual no debe desmayar nunca ante la idea de la negación absoluta. Aunque el mundo se deshaga totalmente, aunque la obra del hombre desaparezca por completo, quedará siempre de su vida, en el seno infinito de la acción, una enerjía ideal susceptible de incorporarse, en forma conocida o desconocida a la sucesiva eternidad (Ideolojía 118).

La conciencia es la personalidad intelectual, el yo trabajado a lo largo de la vida (Alerta 43-5). No sostiene el poeta compartimentos estancos - la sensibilidad, la inteligencia, la conciencia-, sino una realidad psíquica continua, que - como ya sabemos-denomina inteligencia sensitiva, sensibilidad inteligente o conciencia. De allí que no debamos entender la conciencia solo como una dimensión moral: es su propio psiquismo que es capaz de reconocerse a sí mismo en sus cambios sucesivos, en cuanto yo que se crea y desarrolla como una semilla que va convirtiéndose en fruto. Por lo tanto, tiene en Juan Ramón Jiménez la característica de unidad en tanto sujeto que se percibe a sí mismo en el mundo. En otros términos, podríamos denominar a esta característica como mente, ya que la conciencia es actividad mental a la que solo puede tener acceso el propio sujeto y desde ella también conoce el mundo -por ejemplo, cuando sostiene "somos alma" (Ideolojía 408)-. Al igual que Platón piensa que el alma es capaz de vivir de la mejor manera posible en el mundo por poder acceder a una confrontación con 
lo más valioso. El alma es afín a lo divino inmortal e idéntico consigo mismo y vive en contacto con lo eterno (Fedón 79e-80b).

Dicho anhelo se reitera constantemente en Diario y aparece, tal como hemos visto, en algunos poemas del mar. Así en XCV, “¡Qué débil el latido/ de tu corazón leve/ y qué hondo y qué fuerte su secreto!/ Qué breve el cuerpo delicado que lo envuelve de rosas, / y qué lejos, desde cualquier parte tuya/ -y qué no ha hecho-/ el centro de tu alma!" (Diario 123). Destaco ahora el CxIII, "Idilio". El poeta detiene su mirada en un instante que condensa la madre, el niño, el sol, el pájaro, una realidad fecundada por la poesía que se abre a la eternidad (Blasco 302):

Amor y vida/ se funden, como el cielo con la tierra,/ en un esplendor suave/ que es, un instante, eterno!". O el poema Lxxix, “Todo dispuesto ya, en su punto/ para la eternidad./ - ¡Qué bien! ¡Cuán bello!/ Guirnalda cotidiana de mi vida,/ reverdecida, siempre por el método!/ ¡Qué trabajo tan fácil y tan dulce/ para un estado eterno!/ ... Qué trabajo tan largo -dices tú- para solo un momento! (Diario 114).

Este marco nos ayuda a comprender mejor el valor que el poeta entrega a sus lectores: una experiencia recreadora en la que el participante se nutre del hallazgo creador. Son los beneficios de la experiencia recreadora, en tanto invento sucesivo para la vida íntima, y no en el sentido didáctico del que Jiménez siempre huyó: “¿Por qué la poesía no se ha de considerar invento sucesivo para la vida íntima?” (Política 491). La experiencia estética tiene la posibilidad implícita de ayudarnos a reconocer nuestra propia naturaleza presentada en el espejo que constituye la obra de arte. Este espejo, la obra, nos devuelve a nosotros mismos, nos invita a adentrarnos en nuestro propio conocimiento, y estrecha una vinculación entre la obra, nuestro yo y los otros. La emoción tiene claramente una función noética: nos ayuda a conocer, comprender y valorar las inquietudes constitutivas de nuestro propio ser, a reconocer los sentimientos del corazón humano y a hermanarnos en las inquietudes de nuestra existencia. El arte tiene valor porque es huella humana, es donación y llamada de otro que no es ajeno a mí. Por eso dice Gadamer que la obra de arte nos habla a cada uno, como si nos lo dijera directamente (59).

En el poema cxx, escribe concisamente: "Sí. Aprenden de nuestro sueño a ver la vida. Basta" (Diario 137). La poesía crea un ámbito intersubjetivo y supone el cultivo de la conciencia crítica. En esta línea destacan algunos poemas, especialmente de la última sección del texto, y también de la tercera, como por ejemplo, el LxxxviII, "Pesadilla de olores" (Diario 118-9). Desde esta orientación ético-estética la poesía del Diario se abre a una experiencia recreadora, ofreciendo un espacio en el que reconocemos los sentimientos del ser humano, sus inquietudes, su dolor y sus deseos, sus interrogantes y los momentos de plenitud vividos.

El Diario no es un poemario de amor romántico, como quizá podría esperarse al conocer las circunstancias de su creación. En el acercamiento al texto he recordado 
que Juan Ramón Jiménez escribe con motivo del matrimonio con Zenobia Camprubí, su gran amor. Ella aparece en el Diario y, de ese modo, el amor cobra una primacía al modo platónico, es decir, la fuerza impulsora del yo hacia lo mejor de sí, ejerciendo un dinamismo transformador. Tal es el caso de CLI, "Ausencia de un día": "Ahora, soñar es verte,/ y ya, en vez de soñar/ vivir será mirar/ tu luz, hasta la muerte" (Diario 158-9). O el cxxi, "Amor", en el que el yo y la amada se funden con el atardecer en el parque. Es frecuente la identificación con el paisaje como en LVIII, "Ocaso de entretiempo": "Se le ha salido el alma hacia la noche/ y es forma de su cuerpo" (Diario 99) o el poema Lxxxiv, la fusión perfecta de "Tu cuerpo con mi alma, amor/ y mi cuerpo con tu alma” (Diario 117). Ahora bien, de toda la riqueza que se puede destacar del Diario bajo esta lectura de la conciencia, existen dos poemas escritos con motivo de la muerte de dos artistas que el autor admiró. Me refiero a Rubén Darío y a Enrique Granados. Con ello quiero resaltar otro concepto ético-estético que se hace presente: la conciencia compartida o compasiva de la experiencia estética.

Rubén Darío muere el 8 de febrero de 1916; Juan Ramón Jiménez escribe un poema, LXI, fechado el 1 de marzo. "Sí. Se le ha entrado/ a América su ruiseñor errante/ en el corazón plácido. ¡Silencio!/ Sí. Se le ha entrado a América en el pecho/ su propio corazón. Ahora lo tiene,/ parado en firme, para siempre,/ en el definitivo/ cariño de la muerte" (Diario 102). El autor poetiza cómo América sintió, amó, cantó a través de Rubén Darío; quien fue su voz y su auténtico corazón (Blasco 287). De modo que la palabra de Darío permanece, y lo que él cantara está "en todas partes": "Lo que él, frenético, cantara,/ está, cual todo el cielo,/ en todas partes. Todo lo hizo/ fronda bella su lira. Por doquiera/ que entraba, verdecía/ la maravilla eterna/ de todas las edades" (Diario 102). La poesía crea, realiza en belleza y patentiza otra realidad que traspasa los límites temporales, incluso permanece más allá de la muerte de su creador. Juan Ramón Jiménez reconoce en este poema la obra realizada por Darío, a quien admiró desde sus años juveniles.

El otro poema es el dedicado a la muerte de Enrique y Amparo Granados, LXXXI, "Humo y oro". Ambos fallecen el 24 de marzo de 1916, en el barco Sussex, torpedeado por los alemanes, cuando viajaban hacia Europa tras el estreno de Goyescas, el 26 de enero en Nueva York. Juan Ramón Jiménez fecha este poema y lo localiza en "New York, en mi ventana a la calle 11, 27 de marzo, madrugada, con luna amarilla". El poema nos sitúa en un horizonte de compasión coparticipada en la experiencia creadora. Recordemos que Aristóteles sostenía que la compasión constituye un sentimiento que se experimenta ante el sufrimiento inmerecido. En la Retórica (II, 8, 1385 b13- 1386 b 8), concreta la compasión como cierta pena experimentada por un mal que se presenta destructivo o penoso "en quien no lo merece", un mal que uno mismo podría esperar padecer o alguno de los allegados. Vincula el filósofo la compasión al miedo, a la conciencia de que a nosotros mismos nos ocurriera algo semejante. Nos compadecemos de todo lo que, siendo penoso o doloroso, es destructivo o letal como la muerte. Aristóteles destacó también su valor ético, especialmente en Poética, 
(1449 b 24-28). Por tanto, el poema localizado en la madrugada expone el dolor de la despedida y el reconocimiento al amigo muerte. Utiliza imágenes de barcos y sirenas tristes que el poeta oye, escucha tras los cristales: "oigo/ despedirse una vez y otra, entre el sueño [...] entre el sueño de tantos como duermen/ en su definitiva vida viva/ y al lado/ de su definitiva vida muerta" (Diario 115). La muerte rompe la armonía de su alma hecha una en el recuerdo del músico: “iQué lejos, oh qué lejos/ de ti y de mí y de todo, en esto/ -los olivares de la madrugada-,/ al oír la palabra alerta-¡muerte! -/ dentro de la armonía de mi alma/ -mar inmenso de duelo o de alegría-,/ a la luz amarilla/de esta luna poniente y sola, España!” (Diario 115).

Este poema manifiesta el sentimiento compartido de dolor ante la muerte; con ello exhibe cómo el arte se construye también sobre el dolor que compartimos como humanos, en un horizonte existencial que nos hermana y que podemos vivenciar en la experiencia estética creadora y recreadora. Una vez más destaca aquí la riqueza ético-estética del poemario que invita al lector a hacer suyo lo que se muestra ante sus ojos. La experiencia estética adquiere así una comprensión más elevada, resaltando la dimensión ética en la forma poética, fortaleciendo la capacidad de ver y compartir con el otro. Al mismo tiempo, ambos poemas condensan la trascendencia de la experiencia creadora, en el sentido apuntado anteriormente, en la sensibilidad inteligente $\mathrm{y}$ en la inteligencia sensitiva.

\section{Conclusiones}

En sintonía con las palabras del poeta, el "Diario tiene una metafísica que participa de estética”. Por ello me he planteado en este artículo si la dimensión metafísica anunciada contribuye al enriquecimiento del lector y, concretamente, al despliegue de la sensibilidad, la inteligencia y la conciencia del participante o recreador de la obra. El análisis del poemario desde dicho triple cultivo ha destacado la riqueza ontológica de la poesía del Diario que transparenta la realidad creada como un encuentro fenoménico con la naturaleza exaltada, en su dimensión sensible y su valor cognoscitivo para la experiencia recreadora. La experiencia estética creadora se perfila como una nueva forma de ver, con una función de descubrimiento. Este poemario posibilita al lector una nueva mirada a la realidad que ahonda y modifica su visión cotidiana, incluso incrementa su conocimiento y lo enriquece. La valoración de la realidad sensible, su fenomenismo, no es independiente de la creación en palabra, es decir, de la realidad creada que nos invita a comprender esa nueva visión del mundo encarnada en forma. El Diario es palabra que condensa un descubrimiento, una apropiación del mundo; es "contemplación con creación" - como entendió el poeta la experiencia creadora-, que ofrece a los lectores el desarrollo de la inteligencia sensitiva.

Finalmente, el Diario ofrece un horizonte intersubjetivo que nos ayuda a reconocer nuestra propia naturaleza presentada en el poemario. El texto nos invita a una 
experiencia compartida cuya función es noética: nos ayuda a conocer, comprender y valorar las inquietudes constitutivas de nuestra experiencia, a reconocer los sentimientos del corazón humano y a hermanarnos en las inquietudes de nuestra existencia. Esto manifiesta la dimensión ética de la experiencia estética. El Diario nos invita a una reflexión que es conocimiento y autoconocimiento, y contribuye con ello a nuestro desarrollo personal. En el poemario de Juan Ramón Jiménez he destacado, especialmente, el sentimiento de dolor ante la muerte, que pone de relieve cómo el arte se construye sobre el dolor que compartimos en tanto humanos, en un horizonte existencial que nos hermana y que podemos vivenciar en la experiencia estética recreadora. En definitiva, el Diario se muestra como campo de experiencias estéticas que, a la vez que nos conducen a un gozo pleno, impulsan en nosotros lectores a un crecimiento personal, contribuyendo al desarrollo de la sensibilidad, la inteligencia y la conciencia.

\section{Referencias}

Albornoz, Aurora de. “Juan Ramón Jiménez o la poesía en sucesión”. Jiménez, Juan Ramón. Nueva Antología. Barcelona, Península, 1973, pp. 9-90.

Amigo, María Luisa. "Gozo y cultivo. Actualidad de la experiencia estética de Juan Ramón”. Villar, Luis Miguel, editor. Juan Ramón Jiménez. Poesía y pensamiento. Huelva, Universidad, 2008, pp. 17-81.

Aristóteles. Retórica. Madrid, Gredos, 1990.

---. Poética. Madrid, Gredos, 1974.

Azam, Gilbert. La obra de Juan Ramón Jiménez. Continuidad y renovación de la poesía lírica española. Madrid, Editora Nacional, 1983.

Blasco, Javier. "Introducción”. Jiménez, Juan Ramón. Obra poética. Madrid, EspasaCalpe, 2005, pp. 3-5.

Cassirer, Ernst. Antropología filosófica. México DF, FCE, 1971.

Csikszentmihalyi, Mihaly. Fluir. Una psicología de la felicidad. Barcelona, Kairós, 2008. Gullón, Ricardo. Conversaciones con Juan Ramón Jiménez. Madrid, Taurus, 1958.

Francastel, Pierre. La realidad figurativa. Barcelona, Paidós, 1988.

Gadamer, Hans-Georg. Estética y hermenéutica. Madrid, España, Técnos, 1996.

Jauss, Hans Robert. Experiencia estética y hermenéutica literaria. Ensayos en el campo de la experiencia estética. Madrid, Taurus, 1986.

Jiménez, Juan Ramón. El trabajo gustoso (Conferencias). México, Aguilar, 1961.

---. El modernismo (Notas de un curso, 1953). Madrid, Aguilar, 1962.

---. La corriente infinita. Madrid, Aguilar, 1966.

---. Estética y ética estética. Madrid, Aguilar, 1967.

---. Libros de Poesía. Madrid, Aguilar, 1972.

---. Crítica paralela. Madrid, Narcea, 1975. 
---. La obra desnuda. Sevilla, Aldebarán, 1976.

---. Alerta. Salamanca. Universidad de Salamanca, 1983.

---. Ideolojía (1897-1957). Barcelona, Ánthropos, 1990.

---. Y para recordar por qué he venido. Valencia, Pre-textos, 1990.

---. Política poética. Madrid, Alianza, 1992.

---. Obra poética. Javier Blasco y Teresa Gómez Trueba, editores. 2 Vol. Madrid, Espasa-Calpe, 2005.

---. Los mil mejores aforismos. Bilbao, Beta, 2006.

Platón. Fedón, Banquete, Fedro. Madrid, Gredos. 1986.

Pérez Priego, Miguel Ángel. "El género literario del Diario de un poeta recién casado". Actas del Congreso: Juan Ramón Jiménez en su centenario. Cáceres, Universidad de Extremadura, 1981, pp. 101-120.

Rozas, Juan Manuel. "Hodiernismo e irracionalismo en la parte central del Diario". Actas del Congreso: Juan Ramón Jiménez en su centenario. Cáceres, Universidad de Extremadura, 1981, pp. 149-169.

Sanz, María Ángeles. "Reflexiones de Juan Ramón Jiménez sobre la contribución de la poesía al "progreso" espiritual del individuo". Letras de Deusto, no 83, 1999, pp. 253-268.

Recibido: 17 junio 2016 Aceptado: 23 noviembre 2017 